\title{
The Influence of Teaching Tenses through Group Discussion Method towards Student's Achievement in Tenses Mastery
}

\author{
Ade Sudirman ${ }^{1}$
}

${ }^{1}$ Universitas Mathla'ul Anwar

\section{ARTICLE INFO}

\section{Keywords:}

Group Discussion Method

Student's Achievement

English Tenses

\begin{abstract}
This research aims to investigate the influence of teaching English tenses through group discussion method towards student's achievement in tenses mastery at first semester students of English department of Mathla'ul Anwar University, Banten. In this research, writer employs the quantitative approach that based on the result of proposing item tests to respodents of the research. Meanwhile design with the characteristics of experimental method, here the researcher conducted test as an instrument. The research done through three steps: first, the writer selected students of Mathla'aul Anwar University as subjects; second, the writer taught tenses through group discussion method at experimental class, while control class taught by giving homework, the treatment is processed by a pretest, treatment, and ended by posttest, it is done to know which one is more effective towards students' achievement in tenses matery, after that, the writer calculated and analysed the data; the last step is reporting the result. The result of posttest shows us that the mean of experimental class is higher than at control class. The result of calculation of t-test shows that tcount (2.63) is higher than tcritic (1.67) in 5\% level significant. These tell us that teaching tenses through group discussion method is effective to improve the students' achievement in tenses matery. The research hypotheses is "there is significance influence of using group discussion method in teaching tenses towards students' achievement in tenses matery". From all the data above, the writer concludes that his hypotheses is justifiable.
\end{abstract}

This is an open access article distributed under the terms of the Creative Commons Attribution 4.0 International License, which permits unrestricted use, distribution, and reproduction in any medium, provided the original work is properly cited. @ 2018 Ade Sudirman.

\section{INTRODUCTION}

Nowadays, everyone recognizes that English is the first international language and has an important role in cooperating with others in this universe. English takes a part in human life and contributes to almost all aspects, namely social, politic, culture, technology, economic, education, etc.

\footnotetext{
${ }^{1}$ Corresponding author's address: English Education Study Program, Teacher Training and Education Faculty of Universitas Mathla'ul Anwar Banten, Indonesia e-mail: adesudirman03@gmail.com
} 
Being very important, English should be taken into condition in education side. The government considers that English as the first important foreign language in Indonesia should be known and taught at school beginning from elementary school to university. It means, Indonesian students are hoped to know and master to communicate using it in their lives and to interact in this globalization era.

To be able to communicate in English well, it takes four fundamental skills, they are listening, speaking, reading, and writing. In addition, vocabulary and grammar mastery as language components must be learnt and mastered as well. In grammar lesson, students are taught 16 English tenses. Tense has significant rule in studying English. It is important for students to use tenses well, for instance at academic paper, bussines letter, and formal speech. Tense is the verb form that shows the time of the action. Supporting explaining above, it is clear that tense can show us the time of event and it is very useful to use in communicating not only formal but also informal situations.

In fact, most students still have low competence in four English skills and language components. English lessons make them boring and difficult. One of the reasons is the method or technique used by teachers in teaching English. Therefore, it is needed some easy and effective methods to teach English. One method assumed effectice and joyful is group discussion method. It can be applied in teaching English tenses, since it gives more chances for students to discuss and practise the names, forms, and functions of tenses. The writer assumes that this group discussion method is approapriate to motivate students learning tenses. By implementing this method, students have a lot of opportunities to dig up and show their insight about lesson freely. Besides, they are able to have brain storming each others, so it can involve more student's participation in problem solving. Students could express their mind to the others for gaining a good solution as well. In addition, group discussion method can be made a way to practise speaking skill.

The people who are doing disicussing should speak face to face and they must have a goal to achieve. Bormann (1975: 3) says that group discussion refers to more meetings of a group of people who thereby communicate, face to face, in order to fulfil a common purpose and achieve a group goal. It means, group discussion method is a way to gather and meet people who want to discuss face to face about an issue and get a solution. Meanwhile, the number of group disccussion members is at least three people.

Based on the condition above, the writer is interested in investigating the influence of teaching tenses through group discussion method towards student's achievement in tenses mastery.

\section{Student's Achievement in Tenses Mastery}

In learning process, there is a goal which must be achieved in order that it will run well. Teachers expect their students have more knowledges than they had before. Knowing how far the students understand about materials, the teachers usually use an achievement test. Dejnoka and Kapel (1991: 65) state that achievement test is as instrument that measure what a student know or can do.

Based on the explanation above, the writer can conclude that the test is used to measure student's ability at the end of certain range of time. The result of the achievement test shows how far the students have understood the materials. The level of student's understanding can be seen from the scores they get based on the computation of true answer achievement test.

In addition, Dejnoka and Kapel (1991) states that "Achievement is the reaching of specific quantity or quality level by an individual." It means, student's ability can be known through student's achievement of the test. Thus, when the tenses achievement takes place, the students are able to do it well. Also, they have ability to know and comprehend the meaning, forms, functions, and verb used of English tenses. 


\section{Teaching Grammar}

Teaching grammar has become a central aspect of foreign language teaching, besides vocabulary. Both aspects have very important rules in teaching and learning process of language. Wilkins as cited in Thornbury (2002: 13) states, "Without grammar, very little can be conveyed, without vocabulary nothing can be conveyed." It means grammar will help people convey their idea to the others supported by vocabulary. But, in this research, writer focused on grammar only not English vocabulary.

Furthermore, Purpura (2004) states that grammar is defined in terms of grammatical form and meaning, which are available to be accessed in language use. In addition, Harmer (1999) says, "Grammar is a process for making speaker's or writer's meaning clear when contextual information is lacking."

One of the lessons that is taught in grammar is tense. It has an important role in mastering English. By knowing and understanding kinds, formulas and functions of tenses, it can help students use English well. According to Kreidler (1998), "Tense is a system of contrast that locates the general meaning of the proposition in the past, present, or future, from the time-perspective of the speaker."

Meanwhile, Angela Downing and Philip Locke (2006: 352) state, "Tense is the grammatical expression of the location of the events in time." In addition, Nordquist (2018) states that tense is the time of a verb's action or state of being, such as present or past. In short, it can be concluded that tense is the grammatical expression of the location of the event in time, such as past, present or future.

English has 16 kinds of tenses which have various functions and forms. They are divided into two parts, namely fundamental and branch parts. The fundamental part consists of present, past, future, and past future. Meanwhile, the branch part consists of simple, continuous/progressive, perfect, and perfect continuous. The names of English tenses are as follows:

Table 1. Names of English Tenses

\begin{tabular}{llll}
\hline \multicolumn{1}{c}{ Present } & \multicolumn{1}{c}{ Past } & \multicolumn{1}{c}{ Future } & \multicolumn{1}{c}{ Past Future } \\
\hline Simple present & Simple past & Simple future & Simple past future \\
Present continuous & Past continuous & Future continuous & Past future continuous \\
Present perfect & Past perfect & Future perfect & Past future perfect \\
$\begin{array}{l}\text { Present perfect } \\
\text { continuous }\end{array}$ & $\begin{array}{l}\text { Past perfect } \\
\text { continuous }\end{array}$ & $\begin{array}{l}\text { Futuret perfect } \\
\text { continuous }\end{array}$ & $\begin{array}{l}\text { Past futuret perfect } \\
\text { continuous }\end{array}$ \\
\hline
\end{tabular}

In this research, the writer merely focused on Simple Present tense. It was discussed several material relating to this tense. They were function, verbs used, auxiliary verb, time signals, and formula forming. By learning those materials in simple present tense, the students could master and impelement this tense in real communication well at not only writing but also speaking.

\section{Teaching Tenses}

Teaching tenses is one of difficulty that the teachers face in teaching and learning process. The writer thinks it is important for the teachers to explain the main focus of the tenses, like duration of the action itself, and to give some contextual examples based on the tense. If so, students can understand them better. There are many ways in teaching tenses in order that the goal will be got.

In addition, about teaching tenses, Koswara (2011) says that:

When I first teach English tenses, I begin by describing the activities that people do, for example: everyday activities, past activities and future activities. At the same time I draw the 
chart of time on the board showing when those activities happen. After the learners understand this basic concept, I write the conjunction of the verbs, for instance 'did' for the past and 'do' for the present. Then I write full sentence on the board. After that, I ask the learners/students to do the same thing with other verbs. I do this with my students and they feel easy to understand the tenses without teaching them tenses directly.

Based on the explanation above, the writer can conclude that the teacher must have an appropriate technique or method in teaching tenses, the using of formulas at the beginning of learning process is not always right. Describing things or activity in the first is more acceptable way without forgetting vocabularies of the lesson topic. Besides, giving a simple question and using time lines to demonstrate present, past, future, and past future can help students understand tenses fast. Finally, the students are able to write tenses formulas through discussion with others.

\section{Teaching Tenses through Group Discussion Method}

Bormann (1975) says, "A group is defined as being composed of by at least three people." Moreover, Brumfit (1984), says that a group is usually defined as a member of people who interact one another and who receive themselves to be a group. In addition, more specifically, Burgon and Huffer (2002) say, "In teaching, an ideal group should consist of the most eight members." Thus, it can be concluded that a group must have at least three members who can interact each others to discuss about problem and look for solution. Then, to make discussion runs well, it is easier for the group leader in managing his or her group and more effective, the members of group are less than eight persons.

Klippel (1984) says that there are nine ways to organize a group, they are as follows:

a. Fishbowl

All students sit in a big circle.

b. Buzz group

Each group discussion discusses a problem for a few minutes before the solutions are reported to the whole class.

c. Hearing

A group of students sit in front of the class and are asked by other students about a topic.

d. Network

The class is divided into a group which should not have more than 10 students.

e. Market

All students walk around the class, and each of them talks to some others.

f. Onion

The class is divided into equal groups.

g. Star

Four to six groups try to find solution of the problem.

h. Opinion Vote

Each student gets a voting card with numbers from 1 to 5 on it $(1=$ agree completely, $2=$ agree, $3=$ no comment, $4=$ disagree, 5 = disagree completely)

i. Forced Contribution

Make sure all members of the group discuss their opinions in the discussion.

In this research, the writer implemented several types of group works, namely fishbowl, buzz group, and star types.

\section{Discussion}

Discussion is the most natural and effective way for students to learn and master tenses. Penny Ur (1996) states, "Discussion is exchange ideas verbally." Besides , there is a statement which states that the effective way for learning to practise speaking freely in English is by thinking out some problems or situation together through verbal interchange of ideas, or simpler terms to discuss. 
In a discussion, students are given more opportunities by the teacher to express their opinion to solve the problem. By doing discussion, students can share their insight each others, and use time effectively. Golebiowska (1990) says that a discussion is communication activity in which learners keep their own personalities and views. Their task is to come to an agreement of an issue introduced by their teacher. It is in accordance with Penny Ur (1996) who states, "The main aim of discussion in a foreign course may be efficient fluency practice."

Based on the explanation above, the writer concludes that discussion is collective thinking process of some people to understand a problem, find the causes solution.

\section{Group Discussion Method}

The traditional mode of instruction is the lockstep approach in which a teacher interacts with all students in the class following a predetermined set of materials. All students receive the same set in the same sequence, and practically receive the same kinds and amount of input for acquisition. In group discussion, on the other hand, the students study by themselves either following a predetermined set of materials or each makes progress at their space.

Before starting the learning process, the teacher prepares some topics which have relation with English tenses in order to be discussed by students. The students are divided into several groups, each group has four to six members, since it is an ideal number for group work.

In setting group, the teacher usually divides group members based on the seat position or class attendace lists. The students move their seats and bodies, or body only if the seats are bench-like seats facing the students who sit behind or in front of them. Then, the teacher will select a group leader who assumed smart and active for each group. In this case, the leader must be responsible to keep class being active and running well.

There are many reasons in implementing group discussion in teaching tenses, namely a) it helps student understand lesson and improve their critical thinking. Moreover, $b$ ) it helps student discuss a particular problem deeply, and improve self confidence to speak English.

In practicing group discussion method, there are student's etiquette that must become an attention, so the discussion process is able to run well. Those etiquettes are divided into two sides: do and don't.

The etiquette that must do:

1. Speak pleasantly and politely to the group.

2. Respect the contribution of every speaker.

3. Learn to disagree politely.

4. Think about your contribution before you speak.

5. Try to stick the discussion topic. Don't introduce irrelevant information.

6. Be aware of your body language when you deliver information.

7. Agree with acknowledge what you find interesting.

The etiquette that mustn't do:

1. Lose your temper.

2. Shout. Use a moderate tone and medium pitch.

3. Use too many gestures when you speak. Gestures like finger pointing and table thumping can appear aggressive.

4. Dominate the discussion. Confident speakers should allow quieter students a chance to contribute.

5. Draw too much on personal experience or anecdote. Although some tutors encourage students to reflect on their own experience, remember not to generalize too much. 


\section{METHOD}

The objective of this research is to investigate the influence of teaching English tenses through group discussion method towards student's achievement in tenses mastery. The result of the analysis is to find out the more effective method in teaching tenses.

This research was conducted at the first semester students of English Education Department, Teacher Training and Education Faculty of Mathla'ul Anwar University. It is located at Jalan K.H. Mas Abdurrahman, Cikaliung, Saketi - Pandeglang Regency, Banten Province. There were several reasons for considering this campus being research settings of this research. The first, the most of students found difficulty in mastering English tenses, especially when they studied English courses at the first semester. The last one, those courses contained tenses that were appropriate to investigate by group discussion as a teaching method. This research was held for five meetings, in November 2018.

To avoid misunderstanding concerning the use of terminology in the title of this research, the writer felt it was necessary to explain each term used. The terms used in this research are as follows:

1. Teaching tenses means the process of delivering a lesson and creating the situation of the person to learn the verb form and function that show the time of action.

2. A group discussion method is the way of communicative activity in which learners keep their own personalities and views done by the people or things number together.

3. The student's achievement in tenses mastery is the result of what students have studied after conducting teaching and learning process in the form of ability of tenses. Here the writer focused on simple present tense ability after the students were given treatment.

The most of teachers claimed that tenses lesson was difficult part in teaching and learning English. Therefore, they were hoped to have ability on how to motivate students to get understanding at English tenses lesson. The use of discussion group as method in teaching English tenses was expected to be a problem solver in this case, so the students could understand and master tenses well. On the other hand, this method gave more opportunities for students to express their insight, and to motivate them to reach the goal of teaching and learning process fast.

In this research, the writer used experimental method to collect data and investigate the influence of teaching tenses through group discussion method towards student's achievement in tenses mastery. Margono (1996: 110) said, "A research using experimental method compare two groups of the research target, one group gone into special, another group controlled at one particular circumstance which its infleunce made by comparator." Thus, experimental class in this research was used group discussion method, meanwhile control class used lecturing method.

By reffering to experimental method which designing in a specific to awaken data needed to answer a question in a researh using an experimental design, then the writer gave test as instrument to collect data. The achievement tests used were pre and post tests. Each test consisted of twenty questions, namely 10 multiple choices form and 10 essays. Both tests of experimental and control class analyzed using t-test formula.

The data were taken by giving tests as instrument of collecting data. Before teaching, the writer had prepared the material about simple present tense. Each group has the same time, 30 minutes for discussing and 15 minutes for doing test. The process consists of tree steps: pre-test, treatment, and post-test.

To get the result of the test, the witer had to measure the student's answer. The writer gave the score, its scale was $1-10$. The score was used to know the influence of teaching tenses using group discussion method. After that, the writer calculated all data to prove in hypotheses statistic, as follows: 
If $\mathrm{t}$-calculation>t-table: Ho is rejected and Ha is accepted.

If $\mathrm{t}$-calculation<t-table: Ho is accepted and Ha is rejected.

\section{RESULT AND DISCUSSION}

In this section, the writer presented the result of achievement test of the sample both experimental class and control class. Pre-test and post-tst were given in teaching tenses process. The experimental class was used group discussion method, meanwhile the control class was used lecturing method. Then, the test result of those two groups were compared to know whether group discussion method was effective or not.

The data of test were compared in each group to investigate the improvement of student's tenses achievement. To make easy in analysis of collecting data, the writer adopted the following steps:

1. Put the score into table of data statistic.

2. Put the data into table of distribution frequency.

3. Calculate the means of group.

4. Calculate the standard deviation of each group.

5. Analyze the data and calculate them using the formula of T-test.

Here are the data of pre-test and post-test scores of experimental class.

Table 1. Test Result of Experimental Class

\begin{tabular}{ccccc}
\hline Subjects & Pre-test (Y1) & Post-test (Y2) & Gain (Y) & $\mathbf{Y}^{\mathbf{2}}$ \\
\hline S1 & 50 & 65 & 15 & 225 \\
S2 & 60 & 85 & 25 & 625 \\
S3 & 20 & 50 & 30 & 900 \\
S4 & 35 & 45 & 10 & 100 \\
S5 & 55 & 85 & 30 & 900 \\
S6 & 60 & 95 & 15 & 225 \\
S7 & 50 & 70 & 20 & 400 \\
S8 & 60 & 95 & 35 & 1225 \\
S9 & 80 & 95 & 15 & 225 \\
S10 & 65 & 80 & 15 & 225 \\
S11 & 65 & 95 & 30 & 900 \\
S12 & 65 & 95 & 30 & 900 \\
S13 & 75 & 90 & 25 & 625 \\
S14 & 65 & 95 & 30 & 900 \\
S15 & 50 & 75 & 25 & 625 \\
S16 & 60 & 95 & 35 & 1225 \\
S17 & 40 & 75 & 35 & 1225 \\
S18 & 25 & 70 & 45 & 2025 \\
S19 & 45 & 80 & 35 & 1225 \\
S20 & 45 & 90 & 45 & 2025 \\
S21 & 55 & 85 & 30 & 900 \\
S22 & 40 & 80 & 40 & 1600 \\
S23 & 25 & 45 & 20 & 400 \\
S24 & 60 & 95 & 35 & 1225 \\
S25 & 90 & 95 & 5 & 25 \\
S26 & 50 & 80 & 30 & 900 \\
S27 & 50 & 75 & 25 & 625 \\
S28 & 60 & 95 & 35 & 1225 \\
\hline
\end{tabular}




\begin{tabular}{ccccc}
\hline Subjects & Pre-test (Y1) & Post-test (Y2) & Gain (Y) & $\mathbf{Y}^{\mathbf{2}}$ \\
\hline S29 & 35 & 70 & 35 & 1225 \\
S30 & 60 & 80 & 20 & 400 \\
Total & $\sum 1580$ & $\sum 2390$ & $\sum 820$ & $\sum 23450$ \\
\hline
\end{tabular}

Here are the data of pre-test and post-test scores of control class.

Table 2. Test Result of Control Class

\begin{tabular}{|c|c|c|c|c|}
\hline Subjects & Pre-test (Y1) & Post-test (Y2) & Gain $(Y)$ & $\mathbf{Y}^{2}$ \\
\hline S1 & 45 & 65 & 20 & 400 \\
\hline S2 & 35 & 65 & 30 & 900 \\
\hline S3 & 70 & 75 & 5 & 25 \\
\hline S4 & 65 & 80 & 15 & 225 \\
\hline S5 & 35 & 65 & 30 & 900 \\
\hline S6 & 45 & 50 & 5 & 25 \\
\hline S7 & 65 & 70 & 5 & 25 \\
\hline S8 & 55 & 65 & 10 & 100 \\
\hline S9 & 75 & 80 & 5 & 25 \\
\hline S10 & 45 & 55 & 10 & 100 \\
\hline S11 & 65 & 80 & 15 & 225 \\
\hline S12 & 55 & 80 & 25 & 625 \\
\hline S13 & 50 & 45 & -5 & 25 \\
\hline S14 & 50 & 80 & 30 & 900 \\
\hline S15 & 25 & 50 & 25 & 625 \\
\hline S16 & 35 & 60 & 25 & 625 \\
\hline S17 & 55 & 70 & 15 & 225 \\
\hline S18 & 50 & 50 & 0 & 0 \\
\hline S19 & 35 & 40 & 5 & 25 \\
\hline S20 & 55 & 80 & 25 & 625 \\
\hline S21 & 30 & 50 & 20 & 400 \\
\hline S22 & 20 & 35 & 15 & 225 \\
\hline S23 & 40 & 50 & 10 & 100 \\
\hline S24 & 50 & 55 & 5 & 25 \\
\hline S25 & 55 & 50 & -5 & 25 \\
\hline S26 & 60 & 75 & 15 & 225 \\
\hline S27 & 65 & 65 & 0 & 0 \\
\hline S28 & 70 & 80 & 10 & 100 \\
\hline S29 & 30 & 40 & 10 & 100 \\
\hline S30 & 40 & 60 & 20 & 400 \\
\hline Total & $\sum 1470$ & $\sum 1865$ & $\sum 395$ & $\sum 8625$ \\
\hline
\end{tabular}

The mean of experimental class.

$$
\begin{aligned}
& M_{y}=\frac{\sum Y}{N} \\
& M_{y}=\frac{820}{30}=27.33
\end{aligned}
$$

The mean of control class.

$$
\begin{aligned}
& M_{x}=\frac{\sum x}{N} \\
& M_{y}=\frac{395}{30}=13.17
\end{aligned}
$$


Standard Deviation of experimental class used formula as follows:

$$
\begin{aligned}
S D_{y} & =\sum Y^{2}-\frac{\left(\sum Y\right)^{2}}{N} \\
& =23450-\frac{(820)^{2}}{30} \\
& =23450-22413.3=1036.7
\end{aligned}
$$

Standard Deviation of control class used formula as follows:

$$
\begin{aligned}
S D_{x} & =\sum X^{2}-\frac{\left(\sum X\right)^{2}}{N} \\
& =8625-\frac{(395)^{2}}{30} \\
& =8625-5200,8=3424.2
\end{aligned}
$$

After knowing two standard deviation values, the writer used $t$-formula as follows:

$$
\begin{aligned}
& \mathrm{t}=\frac{M_{x}-M_{y}}{\sqrt{\left[\frac{\sum X^{2}+\sum Y^{2}}{N_{x}+N_{y}-2}\right]\left[\frac{1}{N_{x}}+\frac{1}{N_{y}}\right]}} \\
& \mathrm{t}=\frac{13,17-27,33}{\sqrt{\left[\frac{[424,2+1036,7}{30+30-2}\right]\left[\frac{1}{30}+\frac{1}{30}\right]}} \\
& \mathrm{t}=\frac{13,17-27,33}{\sqrt{\left[\frac{[424,2+1036,7}{30+30-2}\right]\left[\frac{1}{30}+\frac{1}{30}\right]}} \\
& \mathrm{t}=\frac{14,16}{\sqrt{\frac{4460,9}{58} \cdot \frac{2}{30}}} \\
& \mathrm{t}=\frac{14,16}{5,39} \mathrm{t}=2.63
\end{aligned}
$$

Table 1 showed that the mean of experimental class was 27.33, meanwhile in table2, the mean of control class was 13.17. In addition, standard deviation of experimental class was 1036.7, on the other hand, control class gost 3424.2. After knowing two standard deviation scores, the writer was able to find out $\mathrm{t}$-test scores, it was 2.63 .

After gaining T-test formula value, the witer looked for the interpretation towards t-calculation or combined with the degree of freedom. By getting 2.63 for $t$-value, then the degree of freedom value in this research was 58. In this case, the writer determined t-critical value based on two tailed test. It is on $5 \%$ level of significance. Because $t$-value is higher than $t$-table, so that Ho was rejected and Ha was accepted. In conclusion, the writer concluded that teaching tenses through group discussion method is effective. It means, there is significant influence of using group discussion method in teaching tenses towards student's achievemnt in tenses mastery.

\section{CONCLUSION}

Tense has an important rule in studying English. It is important for students to know and master it well. Some of the students have difficulty in learning English tenses. Therefore, it is needed a good and right way or method in teaching tenses in English.

Group discussion method is one of approriate methods in teaching English tenses. It helps students understand a subject more deeply. Besides, by using this method, it gives students chance to hear and deliver more ideas among them. Its expectation is students have a good achievement in tenses mastery. So that, the goal of teaching and learning process will be got well and fast.

This research shows that student's achievement in tenses mastery which uses group discussion method gets higher score in experimental class than control class. In addition, this method gives significant influence towards student's English tenses mastery. 
After the writer conducted the research, he proposed the following suggestion as follows:

1. English teacher should be able to create or implement an interesting atmosphere in classroom by managing the class and using appropriate methods depend on student's needs.

2. The motivation is the most important factor in learning, hence, an English teacher should be able to encourage students in learning English.

3. The English teacher is hoped to be more creative on assisting students in learning English, especially in teaching tenses.

4. Group discussion method can be used in teaching English tenses.

\section{REFERENCES}

Bormann, Ernest G. (1975). Discussion group methods: theory and practice, 2nd edition. New York: Harper \& Row.

Brumfit, C. (1984). Communicative methodology in language teaching: the roles of fluency and accuracy. Cambridge: Cambridge University Press

Burgon and Huffner. (2002). Human communication. London: Sage Publication.

Dejnoka, E.L and D E. Kapel. (1991). Reading. New York: Green Press.

Downing, A and Locke, P. (2006). English grammar: A University Course Second Edition. Oxon: Routledge.

Golebiowska, A. (1990). Getting students to talk. London: Prentice Hall, Inc.

Harmer. J. (1999). How to teach grammar. Harlow: Pearson Education Limited.

Klippel, F. (1984). Keep talking: communicative fluency activities for language teaching. Cambridge: Cambridge University Press.

Koswara, A. A. (2011). Ungkapan sehari-hari dalam Bahasa Inggris. Jakarta: Trans Media.

Kreidler, C. W. (1998). Introducing English Semantics. New York: Routledge.

Margono. (1996). Metodologi penelitian pendidikan. Jakarta: PT Rineka Cipta.

Nordquist, R. (2018). Understanding verb tenses. Retrieved on November, 52018 from https://www.thoughtco.com/tense-grammar-1692532

Purpura. J. (2004). Assessing grammar: Cambridge: Cambridge University Press.

Thornbury, S. (2002). How to teach vocabulary. Harlow: Pearson Education Limited.

Ur, P. (1996). A course in language teaching. Cambridge: Cambridge University Press. 